\title{
ENSURING COMPETITIVE ADVANTAGE THROUGH INNOVATION CAPABILITY AND CLUSTERING IN THE THAI AUTOMOTIVE PARTS MOLDING INDUSTRY: A SEM APPROACH
}

\author{
Corresponding author: \\ Sirorath Tiengtavaj \\ Faculty of Administrative and Management \\ King Mongkut's Institute of Technology Ladkrabang \\ Chalongkrung Rd. Ladkrabang, Bangkok, 10520 Thailand \\ phone: +66 (0) 23298459-60 \\ e-mail: golfgolfss@lm.co.th
}

Sirorath Tiengtavaj, Thepparat Phimonsathienand, Wanno Fongsuwan

King Mongkut's Institute of Technology Ladkrabang (KMITL), Faculty of Administrative and Management, Thailand

Received: 1 July 2016

Accepted: 2 September 2017

\section{ABstract}

Thailand hosts over 50 percent of the world's top OEM automotive parts suppliers and additionally is home to over 2,400 Tier 1-3 manufacturers and suppliers. Given the significance of these numbers and Thailand's leading ranking and contribution to the global automotive industry, research was undertaken to determine how manufacturing clusters and innovation capability effect competitive advantage as it relates to automotive production part management. Multiple objectives were established which included the study of the effects and overall influences of the various variables on competitive advantage as well as the development of a structural equation model (SEM) to define how innovation and manufacturing clustering affects the competitive advantage within the Thai automotive parts molding sector. Quantitative methods analysis was conducted on the data from 240 automotive production and components suppliers' questionnaires collected from industry managers with the research results partially obtained from the analysis by use of (PLS)-graph. Qualitative research was also obtained by use of purposive sampling from in-depth interviews from ten senior managers. The results obtained indicated that clusters and innovation capability has a significant and positive effect on competitive advantage. Thus, the findings from the research illustrate that if an organization focuses on clusters, there will be a knock-on effect within the automotive parts groups leading to the increase in innovation capability, which creates a greater competitive advantage, not only for the enterprises, but also for Thai society as well.

KEYWORDS

manufacturing clusters, molding industry, moulding industry, structural equation model, Thailand.

\section{Introduction}

The global market for dies and molds exceeds \$US 100 billion dollars and is concentrated in the BRIC countries, the European Union and North America [1].

With the rise of Thailand as the "Detroit of Asia", the molding industry for auto parts has become an ever increasing important sector to Thailand and the 10-nation Asean (Association of Southeast Asian Nations) community [2].

This shift towards Asia can best be understood by knowing that China became the biggest consumer of automobiles in the world with data from the China Association of Automobile Manufacturers stating that in 2013 the number of car sales in China reached nearly 22 million vehicles, an increase of nearly 14 percent from the previous year, with both Chinese car production and sales becoming the largest in the world [3].

One sector which is also undergoing hyper growth is the supporting automotive, plastic injection molding sector as 90 percent of automotive parts are now produced by molding technologies (Fig. 1).

In 2015, Thailand produced 1.9 million vehicles with 1.2 million destined for export. There were al- 
so 1.8 motorcycles produced, with exports reaching 350,000 units [4].

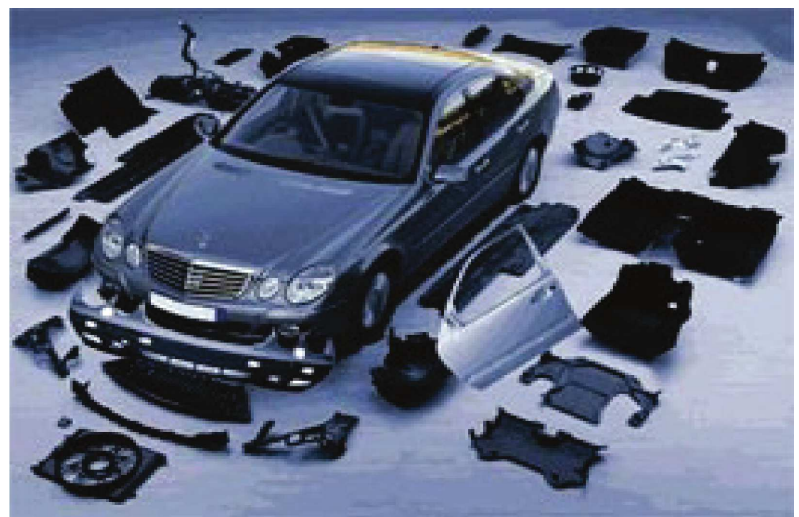

Fig. 1. Automotive molding parts.

Added to this, cross-border value chains have become larger and more complex, integration of ASEAN trade has the ability to be more complementary rather than competitive. Where before protectionism was deemed a mechanism of economic and national survival, many today view it as irrelevant and even self-penalizing as foreign direct investments across ASEAN economies rose from \$US 4.26 billion in 1990 to $\$$ US 20.04 billion in 2012 to $\$$ US 136.2 billion in 2014 [5].

\section{Auto parts molding}

In general, mold import and exports are divided into two categories of molds and dies. The vast majority of dies (70 percent) are imported from Japan, while 13 percent come from Korea and 7.5 percent originating in China. For molds, 50 percent are imported from Japan, 13.9 percent from China, 11.1 percent from Taiwan and 9.3 percent from South Korea [6]. Due to Japan's sector strength, Japananese enterprises have become the largest sector exporter, accounting for 40 percent of the total.

Downstream manufacturing faciltiies also require input from molds and dies enterprises which has contributed to Thailand becoming a regional export hub which has allowed local equipment and parts suppliers to gain benefits from the economic growth of its neighbors and the favorable trade relations upon the initation of the ASEAN Free Trade Agreement (AFTA). Due to these factors, Thai exports within the sector grew to nearly $\$$ US 12 billion, which was a 190 percent growth rate over the previous nine years $[6]$.

The trend of export growth looks likely to continue as demand from developing neighbor countries such as Vietnam, Malaysia and Indonesia continuing to increase, with Indonesia in 2016 projected to produce over one million vehicles.

Research from the Thai Tool and Die Industry Association (TDIA) indicate there are 1,061 mold and die factories in Thailand with 90 percent producing molds and dies for plastic and metal. Of these, the majority are used by Thailand's automotive and E\&E industries [6]. Quality and uniformity are critical with physical characterisitcs and consistency critical to the manufacturing process, whether using metal, rubber, glass or plastic molds.

Innovation is difficult to replicate through the marketing process, but you need innovation to create successful business [7] and the need for capacity building by creating work linking interface concepts and activities of public and private sector policies and measures to support the industry.

The quality of production must also be enhanced to minimize losses within the production cycle. It is also necessary to develop staff at all levels within an organization which have the ability to respond to the needs of the auto parts industry. Thus industry vision within the automotive parts sector needs a guide to help with development. These main points include:

1. Focus on adding value in molded parts production as well as increasing the quality and precision which can shorten production time. This also includes the development of surface polishing mold and die processes (Fig. 2).

2. Infrastructure development which supports the industry and establishes better quality standards for the molding process. Raise mold standards to international levels while establishing an independent body to coordinate the various governmental, private sector and university organizations (Fig. 2).

3. Develop organizations to help better increase their competitive advantage by promoting the integration and specialization of the work force. Help with entrepreneurial collaboration throughout the supply chain by supporting measures to reduce the import duty on raw material and machinery. This needs to be coupled with the development of marketing channels to achieve a good image that is recognized internationally [8] (Fig. 2).

After an analysis of the problems and the associated reasons, the researchers developed a SEM to evaluate the structure of innovation capabilities and clusters that affect the organization's competitive advantage. 


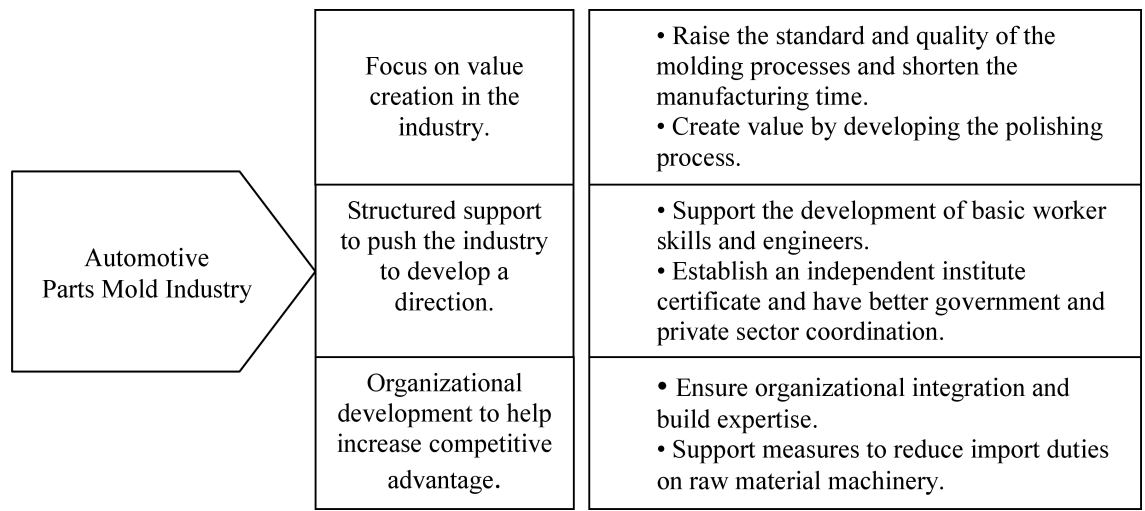

Fig. 2. Development guide for automotive parts molding industry [8].

After a review of the literature it was determined that factors influencing organizations committed to clusters are centralized laboratories, organizational knowledge bases, technology cooperation and joint ventures which helps organizations to build innovation capability.

The variables that innovation affects for this study was identified to consist of products, processes, services, and technology, which are related to providing organizations with more efficient management of cost, quality, delivery and flexibility. This is turn helps automotive parts molding enterprises to direct their strategy, objectives and goals, and policies to meet the organization's competitive advantage.

\section{The study's objectives}

- To determine how competitive advantage is affected, both directly and indirectly, by the various components of innovation and manufacturing clusters as it realtes to Thailand's automotive parts molding industry.

- The development of a SEM to determine the effects of clustering and innovation on competitive advantage.

\section{Literature review}

\section{Competitive advantage}

A competitive advantage becomes sustainable when other companies cannot duplicate the benefits it provides and has. To compete effectively and achieve a sustainable competitive advantage, the organization needs to employ Porter's 'generic strategies' including the ability to maintain cost leadership, provides products and services which are unique, and maintain a direction and focus [10].

Additionally, factors that determine competitive advantage are determined by:
- Domestic production, resources and labor.

- Domestic demand and market share.

- Competitive strategy, differentiation strategy, strategic cost and strategy aimed at individual differences and strategy aimed at individual cost.

- Related and supporting industries in the country and the supply chain.

The current environment has increasingly fierce competition with changes in the range of products resulting from rapid changes in technology to meet customer needs, with organizations needing to develop new products in order to be competitive.

For several decades, many researchers have been convinced that the ability to innovate new products influences the survival of the organization and the organization's ability to thrive.

However, some researchers have noted that organizations often fail to produce new products and ignore the importance of the integration of knowledge and the links between customers and suppliers. The inability to develop new products leads to an organizations eventual demise [11], thus creating a competitive advantage in the industry of automotive parts. It is important that every organization has the ability to focus and measure the needs of customers which meet their needs [12].

1) Cost is a factor which needs to be considered both in the internal and external environments. In particular, businesses can reduce internal management costs as well as reducing and shortening the development and manufacturing process. Resource management in organizations is a cheap and effective technique to accomplish this [13-17].

2) Quality is a factor which needs to respond to customer expectations by producing a more valuable product or offering a service higher than that of the competition and aiming for higher customer satisfaction which meets or exceeds customer expectations [18-22]. 
3) Delivery is defined within an organization as a leader in delivering excellent value to its clients by creating an innovative culture and organizational structure through the entire process of operations and management which creates value which delivers a quality product on time to the customer $[20,23-$ 26].

4) Flexibility or the ability to respond quickly is very important. Organizations must be able to work with the shortest possible time and have flexibility in the production process. Effectiveness and efficiency of an organization can be achieved by creating an environment that gives importance to the immediacy of the work that happens within that organization [24, 27-29].

\section{Clusters}

Cluster policy can be better understood as a larger set of specific government policy interventions aiming at strengthening existing clusters or facilitating the emergence of new ones. Clusters traditionally are developed around areas where specific groups of industries have gathered, which make use of the strengths of closeness, innovation capabilities, educational and research facilities [30].

Global competitiveness is enhanced due to the ability of firms to collaborate in the use of resources, information, and innovative technologies. Research has shown that firms which are more technological advanced, integration can lead to greater profitability. However, for less advantaged enterprises, maintaining lower levels of integration to achieve the benefits of specialization is the better strategy [31, 32].

1) Centralization Laboratory is an idea which uses development of new products as part of the ability to succeed. With it, there must be cooperation and linking of all parties to work with the research and development process within the organization. The organization must constantly strive to develop and build organizational strength to maintain and sustain a competitive advantage [32, 33, 35].

2) Organizational Knowledge Bases are used to study and learn from prior knowledge, such as technology, processes, people and information. The creation of new products is Innovation which creates benefits across the organization helping maintaining and improving a better competitive advantage in the market place [32, 34, 35, 37].

3) Technology Cooperation is the technical complexity of technological developments in the automotive industry which relies on molding processes for the vast majority of the auto parts sector. Given the fast paced changes of the auto brands it is difficult to bean expert in all the required tech- nologies which therefore necessitates cooperation and technology exchange throughout the supply chain. It might also be possible to jointly purchase the required technology and conduct research and development together [33, 35, 36, 38].

4) Joint Ventures' success can depend on the ability of the relationship members to open up new markets and distribution channels as well as the ability to increase production capacity when required. Joint ventures (JVs) also permit the partners to share the risks and costs, while giving easier access to resources such as technical expertise, technology and financing. A JV can also greater flexibility to the members and the ability to react to market conditions quicker [32, $39-41]$.

\section{Innovation capability}

According to research from Liu and Wei [14], business model innovation is a new way for Chinese firms to compete in the global economy. It was concluded that future success of new Chinese firms depends on the continuous improvement of their business model.

1) Product Innovation today is focused on managing R\&D for business growth and quickening the pace of innovation while integrating technology planning with the business strategy. However, innovation can upset and distort traditional economic principles concerning the sale of tangible and intangible goods, such as the use of the Internet for commerce [42-46].

2) Process Innovation deals with the optimization of capabilities within the organization, with research and development both with in and outside the organization driven to focus on quality control and improve productivity and sustainability $\left[1,43,46^{-}\right.$ 49].

3) Technology Innovation is concerned with the process of information flow and collaboration with helps with the stimulation and creation of new processes, products, and markets. Entrepreneurs play a large role in technology innovation as they often times have the ability to translate their vision and knowledge into business opportunities, which often times leads to product innovation [23, 46, 49-51].

4) Service Innovation combines innovative processes, innovation technology and innovation through the implementation of new ideas and concepts. Used in a systematic manner to create a different service which meets needs and satisfaction of customers and undertake a process which always meets or exceeds customer expectations [13, 23, 52-54].

After a review of the literature, the researchers generated the following three hypotheses (Fig. 3): 
Hypothesis 1 (H1): Clusters directly and positively affects Innovation Capability.

Hypothesis 2 (H2): Clusters directly and positively affects Competitive Advantage while also indirectly affecting Competitive Advantage through Innovation Capability in a positive way.

Hypothesis 3 (H3): Innovation Capability significantly affects Competitive Advantage in a direct and positive way.

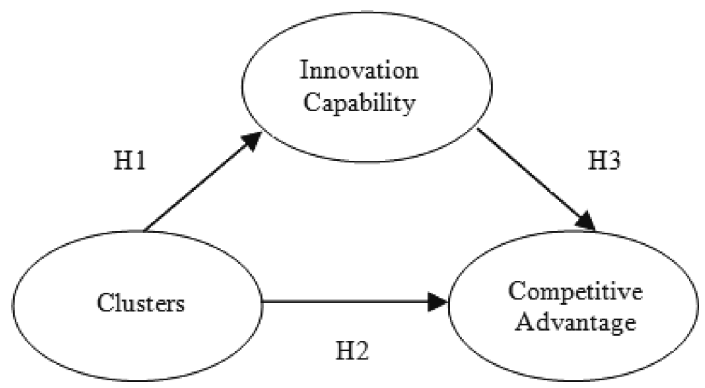

Fig. 3. The conceptual framework.

\section{Methodology}

\section{Data collection and analysis}

Schumacker and Lomax [55] discussed the various models used to study the observed variables in SEM analysis and indicated that the developed models can be used to display how multiple variables define concepts and how they are related. Furthermore, SEM modeling helps show the extent to which the research data is supported and given its complexity of analysis, is the preferred method for quantitatively confirming theoretical models.
Sample sizes have also been a significant focus of research with many researchers indicating that a sample size of at least 100 is recommended in SEM research [55-58] and sizes less than this should not be used [59]. Furthermore, Schumacker and Lomax recommended that a sample size of 20 should be used for each observed variable so since the research consisted of 12 variables, a minimum of 240 were deemed acceptable [55-60, 62-64].

Therefore, 240 individuals' surveys were obtained from Thai automotive parts manufacturers and enterprises clustered in industrial estates in Bangkok, Samut Prakan, Rayong and Chonburi Provinces.

\section{Quantitative measurement}

Competitive advantage analysis of Thailand's automotive molding sector was partially developed by use of a 7-Point Likert Scale [61] questionnaire. Additionally research tools were created from the conceptual framework and review of related literature as indicated in Table 1 below.

\section{Measurement model results}

The study made use of Cronbach's alpha to evaluate the initial questionnaire samples which used a 7 -point Likert rating scale. The values of alpha $(\alpha)$ that are considered acceptable, range from a value of 0 to 1 and may be used to describe the reliability of factors extracted from multi-point formatted questionnaires or scales, with a reliability score of 0.70 or higher being considered a reliable score by many researchers [60]. Results showed that the study's average value of the correlation coefficient was between 0.755 to 0.898 , which indicates the results to be highly reliable.

Table 1

Research question development.

\begin{tabular}{|c|c|c|}
\hline External variable & Manifest variables & Research question development \\
\hline \multirow{4}{*}{ Clusters } & Centralized laboratories & {$[32,33,35,47]$} \\
\hline & Organizational knowledge base & {$[32,34,35,37]$} \\
\hline & Technology cooperation & {$[33,35,36,38]$} \\
\hline & Joint ventures & {$[32,34,35,37]$} \\
\hline Intermediate variable & Manifest variables & Research question development \\
\hline \multirow{4}{*}{ Innovation capability } & Product innovation & {$[43-46]$} \\
\hline & Process innovation & {$[1,43,46,48,49]$} \\
\hline & Technology innovation & {$[23,46,49-51]$} \\
\hline & Service innovation & {$[13,23,52-54]$} \\
\hline Latent variable & Manifest variables & Research question development \\
\hline \multirow{4}{*}{ Competitive advantage } & Cost & {$[13-17]$} \\
\hline & Quality & {$[18-22]$} \\
\hline & Delivery & {$[20,23-26]$} \\
\hline & Flexibility & {$[24,27-29]$} \\
\hline
\end{tabular}


Table 2

Statistic values presenting convergent validity of reflective scales of latent variables.

\begin{tabular}{|c|c|c|}
\hline Construct/Item & Loading & t-stat \\
\hline \multicolumn{3}{|l|}{ Clusters (Clusters) } \\
\hline Centralized Laboratories (Central_lab) & 0.8276 & 33.8915 \\
\hline Organizational Knowledge Base (Know_org) & 0.8237 & 37.2846 \\
\hline Technology Cooperation (Tech_coop) & 0.7792 & 21.6344 \\
\hline Joint Ventures (Joint_ven) & 0.8305 & 36.8255 \\
\hline \multicolumn{3}{|l|}{ Innovation Capability (Innovation) } \\
\hline Product Innovation (Prod_inno) & 0.9097 & 67.4003 \\
\hline Process Innovation (Proc_inno) & 0.8853 & 45.7122 \\
\hline Service Innovation (Service_inno) & 0.8999 & 56.6310 \\
\hline Technology Innovation (Tech_inno) & 0.8701 & 41.4467 \\
\hline \multicolumn{3}{|l|}{ Competitive Advantage(Competitive) } \\
\hline Cost (Cost) & 0.8347 & 28.0784 \\
\hline Quality (Quality) & 0.8392 & 24.9986 \\
\hline Delivery (Delivery) & 0.9168 & 76.7325 \\
\hline Flexibility (Flexibility) & 0.8865 & 55.3907 \\
\hline
\end{tabular}

Table 3

Confirmatory factor analysis (CFA) of the independent variables.

\begin{tabular}{l|c|c|c|c|c|c}
\hline \multirow{2}{*}{ Construct } & \multirow{2}{*}{$\mathrm{CR}$} & \multirow{2}{*}{$\mathrm{R}^{2}$} & $\mathrm{AVE}$ & \multicolumn{3}{|c}{ Cross construct correlation } \\
\cline { 5 - 7 } & & & & Clusters & $\begin{array}{c}\text { Innovation } \\
\text { capability }\end{array}$ & $\begin{array}{c}\text { Competitive } \\
\text { advantage }\end{array}$ \\
\hline Clusters & 0.888 & & 0.665 & 0.815 & & \\
\hline Innovation capability & 0.939 & 0.5529 & 0.795 & 0.744 & 0.892 & 0.870 \\
\hline Competitive advantage & 0.926 & 0.7870 & 0.757 & 0.773 & 0.866 & \\
\hline Note: CR - composite reliability; R2 - square of the correlation; AVE - average variance extracted. \\
Notes: Statistical significance level is at 0.01 and diagonal figures mean.
\end{tabular}

Table 4

Research hypotheses test results.

\begin{tabular}{l|c|c|c}
\hline Hypotheses & Coef. & t-stat & Results \\
\hline Hypothesis 1 (H1): Clusters directly and positively affects innovation capability & .744 & 24.9705 & confirmed \\
\hline $\begin{array}{l}\text { Hypothesis 2 (H2): Clusters directly and positively affects competitive advan- } \\
\text { tage while also indirectly affecting competitive advantage through innovation } \\
\text { capability in a positive way. }\end{array}$ & .290 & 5.2272 & confirmed \\
\hline $\begin{array}{l}\text { Hypothesis 3 (H3): Innovation capability significantly affects competitive ad- } \\
\text { vantage in a direct and positive way. }\end{array}$ & .650 & 14.1625 & confirmed \\
\hline
\end{tabular}

Although many social scientists disagree on what constitutes adequate validity, for this research convergent validity (e.g., having adequate AVE) was one method used $[63,64]$. From this, the results in Table 2 are shown where all values greater than 0.707 are deemed to be statistically significant $(|t| \geq 1.96)$ representing convergent validity of scales [63, 64]. Furthermore, the reflective model in Table 2 indicates the discriminant validity of the internal latent variables and the correlation of variables.

Table 3 shows the results from the competitive advantage factor analysis where the composite reliability (CR) values are higher than 0.60 , with all resultant average variance extracted (AVE) values higher than 0.50 , and all square of the correlation $\left(\mathrm{R}^{2}\right)$ values determined to be higher than 0.20 , representing the overall reliability of the measurements $[59,60]$.

In order to establish discriminant validity there is need for an appropriate AVE (Average Variance Extracted) analysis in which the square root of every AVE value belonging to each latent construct is tested to determine if it is much larger than any correlation among any pair of latent constructs [59]. From the study's analysis of $\sqrt{\mathrm{AVE}}$, it was determined that they have higher values than all of the corresponding values in the 'Cross Construct Correlation' in the same column, representing discriminant validity of the measure in each construct as shown in Table 3. 


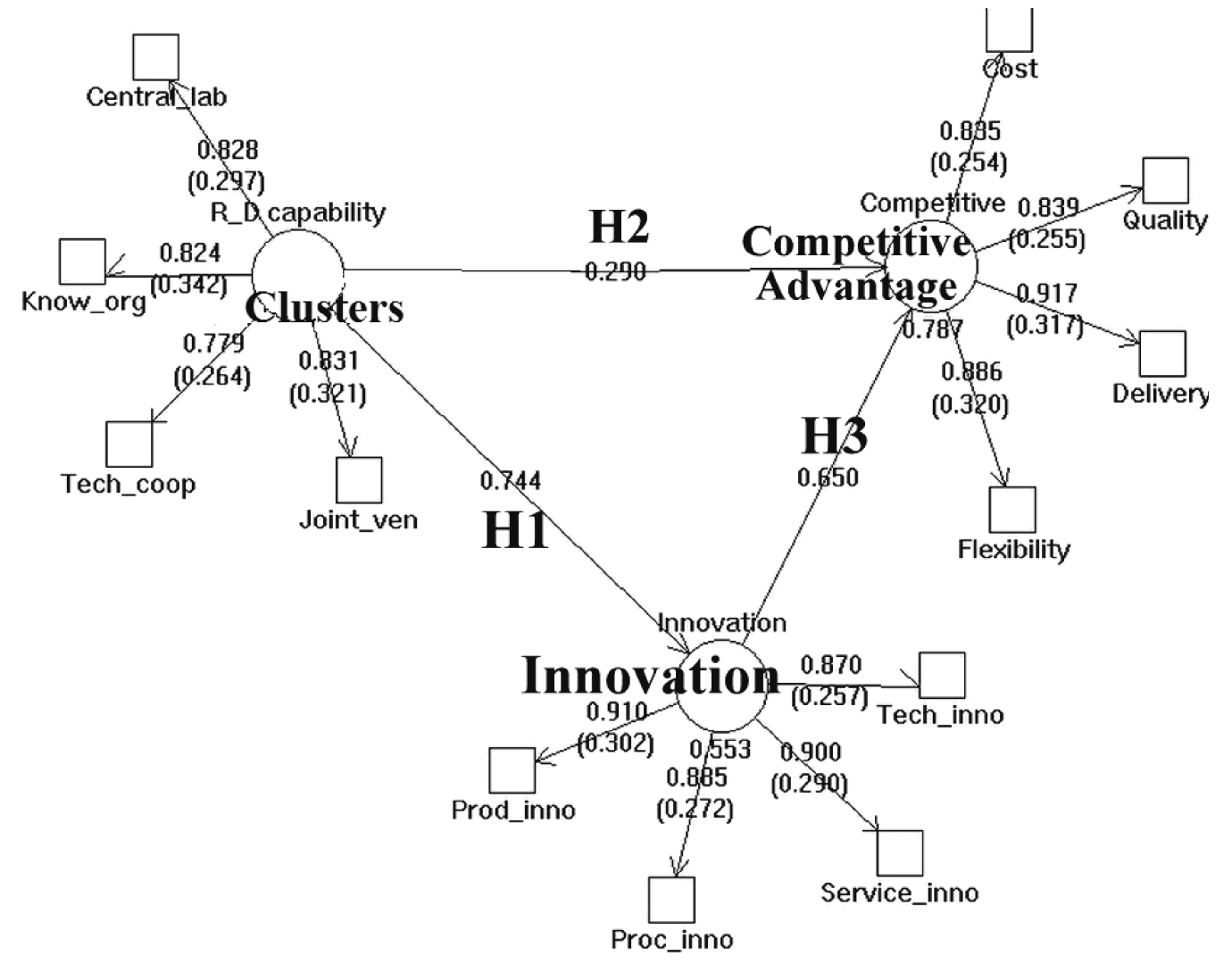

Fig. 4. Final model.

Results obtained from t-test coefficient analysis relationships are shown in Table 2 as well as the test results presented in Table 3 below.

Clusters' (Clusters) factors included Centralized Laboratories (Central_lab), Organizational Knowledge Bases (Know_org), Technology Cooperation (Tech_coop) and Joint Ventures (Joint_ven) with values of $0.828,0.824,0.779$, and 0.831 , respectively.

Additionally, there was a 95 percent confidence interval $(|t| \geq 1.96)$, which reflects a significance level of 0.05 which considers such factors as highly reliable. Clusters (Clusters) was determined to directly and positively affect Innovation Capability, as can be seen from $\beta=0.744$ and $p<.001$ (Fig. 3).

Innovation Capability (Innovation) factors included Product Innovation (Prod_inno), Process Innovation (Proc_inno), Service Innovation (Service_inno) and Technology Innovation (Tech_inno) with values of $0.909,0.885,0.899$, and 0.870 respectively.

Additionally, there was a 95 percent confidence interval $(|t| \geq 1.96)$, which reflects a significance level of 0.05 , which is considered highly reliable. The model confirms that adoption of Clusters by automotive enterprises could increase Innovation Capability as indicated by the direct and positive effect on Competitive Advantage $\beta=0.650$ and $p<.001$, which supports both Hypothesis 1 and Hypothesis 3 .

Also, Clusters positively and directly influences Competitive Advantage $(\beta=0.650$ and $p<.001)$ as indicated by the external variables including Cost (Cost), Quality (Quality), Delivery (Delivery) and Flexibility (Flexibility) with values of $0.834,0.839$, 0.917 and 0.887 , respectively.

Additionally, there was a 95 percent confidence interval $(|t| \geq 1.96)$, which reflects a significance level of 0.05 which is considered as highly reliable, which supports Hypothesis 2 (Fig. 4 and Table 3).

In Table 3, the Confirmatory Factor Analysis (CFA) of the independent variables of Clusters and Innovation Capability on the dependent variable of Competitive Advantage in the Thai automotive parts molding is shown.

\section{Discussion and results}

Due to the rapid and accelerating changes in customer needs, the Thai automotive molding sector must necessitate change to remain competitive in a rising sea of global competition. Industry leader- 
ship changes fast, and Thailand must not rest on its laurels from previous successes.

Innovation and knowledge gained from collaboration are also key elements in the process leading to competitive advantage. Joint ventures where trust and communications exist are crucial elements in profitability and competitive advantage as well.

This study's results are in agreement with Huang [65] who wrote about the crucial importance of international JVs for internationally focused enterprises to maintain a competitive advantage and felt that collaboration, knowledge transfer and learning processes were the primary responsibility of the JV's parent company.

These results were also confirmed by Ahmad and Schroeder [66] which investigated the effects of learning-based technology and procedures on plant competitiveness. It was determined that a key element was worker input and feedback, which had a significant contribution to plant competitiveness.

The use of collaboration technology is the driving force behind innovation which positively affects competitive advantage $[43,65,66]$.

\section{Suggestions for bringing this research into industry use}

Results from the study showed that the current operators in the Thai auto parts industry lack strong links with production, delivery, and after-sales service. Furthermore, effective management is lacking.

As in many developed countries which are developing their enterprise networks and linking their entrepreneurs with clusters, these networks have tremendous trade advantages. Developing nations have begun the process of studying development strategies based on clustering and networking to enhance the competitiveness of their enterprises.

Technology must be enabled and collaborative use of the Internet must be a priority. Additionally, it is imperative that entrepreneurs are clearly made aware of the clustering concept so that they can realize the power realized from working together to analyze obstacles and find creative solutions for the overall benefit of the sector.

Additionally, for the network clustering initiative to succeed, it must receive full government support, including the issuance of new regulations. There must also be cooperation in R\&D across multiple agencies, the governmental sector and universities across Thailand.

There must also be investment in infrastructure with operational support and cooperation from the agencies and organizations involved, both in the public and private sectors. This is essential for the support of the development of the industry and is a major force in driving the industry to achieve the goals and objectives set.

More specifically, the Thai molding industry cluster initiative needs to be well organized with links into the supply-chain and its development. Foreign direct investment (FDI) as well as market intelligence, and incubator services, are also driving forces. Management training, and marketing across the Asean Economic Community (AEC) while setting and achieving high technical standards is also required.

As Porter indicated, clusters affect competitiveness within nations as well as across international borders [69] and while clustering might be a higher form of competitive advantage, it might also be the foundation for industry survival.

\section{Conclusions}

This study examined the concepts of innovation capability and clusters and determined that they are driving forces in Thailand's automotive parts molding industry ability to sustain a competitive advantage.

According to the Thai National Industrial Development Master Plan (2012-2031) [8], Thailand needs to develop its mold and die industry quickly which is a critical component of the overall industrial sector, which will lead to greater competitive advantage within Thai enterprises.

Quality and uniformity are paramount at achieving success with the production quality critical to minimizing losses and gaining better profitability. Staff development is also necessary at all levels within an organization with the importance of responding to customer needs crucial. Strategic vision needs to be a guide to assist with the development process as well.

Furthermore, the findings confirm other researchers' conclusions concerning the importance of innovation capabilities and how critical this is to the process of innovation both in and outside an organization. Firms must make a commitment to a process of continual innovation and invest in clusters where product $\mathrm{R} \& \mathrm{D}$ and manufacturing technology is continually enhanced to ensure competitiveness and growth.

Industry managers and academic researchers should take notice that it is imperative that entrepreneurs are clearly made aware of the clustering concept so that they can collaborate togeth- 
er to analyze obstacles and find creative solutions for the overall benefit of the industry. For the network clustering initiative to succeed, it must receive full government support, including the issuance of new regulations. If entrepreneurs and Thai government agencies implement these research results, it might be a foundation for a sustainable and profitable solution to an otherwise hyper-competitive environment. There must also be cooperation in $R \& D$ across the academic community, state agencies, and governmental ministries in Thailand. More specifically, the Thai molding industry cluster initiative needs to be well organized to attract foreign direct investment, management training, and better marketing access across the Asean Economic Community (AEC) while setting and achieving high technical standards. These issues as well as technical knowhow and technical skills, machinery precision capability and collaborations, are recommended for further research.

\section{References}

[1] Jhavar S., Paul C.P., Jain N.K., Causes of failure and repairing options for dies and molds: a review, Eng. Fail. Anal., 34, 519-535, 2013, http://dx.doi.org/10.1016/j.engfailanal.2013.09.006.

[2] BOI, Thailand: The Detroit of Asia, Board of Investment (Thailand), 2012, https://tinyurl.com/qy4ynpq [accessed on September 1, 2016].

[3] China AutoWeb, China Auto Sales Hit Record High of 21.98 Million in 2013, 2014,

https://tinyurl.com/qgengo2 [accessed on November 8,2015$]$.

[4] Thailand automotive industry overview, http://tinyurl.com/z2445y9 [accessed on September 1, 2016].

[5] ASEAN investment report 2015: Infrastructure investment and connectivity,

http://tinyurl.com/h44ey6t [accessed on September $1,2016]$.

[6] TIR, Molds \& Dies Industry, Thailand Investment Review, August, 2013,

https://tinyurl.com/nw8qmse [accessed on September 1, 2016].

[7] Lindgardt Z., Reeves M., Stalk G., Deimler M.S., Business model innovation, Boston Consulting Group, December 2008,

http://tinyurl.com/hhyqbr8 [accessed on September $2,2016]$.

[8] TAI, Master Plan for Automotive Industry 2012 2016, Thailand Automotive Institute and Ministry of Industry, 2012, https://tinyurl.com/zpmwne5 [accessed on September 2, 2016].

[9] Byrd T.A., Turner D.E., An exploratory examination of the relationship between flexible IT infrastructure and competitive advantage, Inform. Manag., 39, 41-52, 2001,

http://dx.doi.org/10.1016/S0378-7206(01)00078-7.

[10] Porter M.E., Competitive Advantage Creating and Sustaining Superior Performance, New York, USA: The Free Press, 1985.

[11] Tepatanapong A., Thai manufacturing sector: Potential and opportunities, Office of Industrial Economics, https://tinyurl.com/zlr3qvd [accessed on September 1, 2016].

[12] Lin M-J.J., Chen C-J., Integration and knowledge sharing: transforming to long-term competitive advantage, Int. J. Organ. Anal., 16, 83-108, 2008, http://dx.doi.org/10.1108/19348830810915514.

[13] Sigalas C., Economou V.P., Georgopoulos N.B., Developing a measure of competitive advantage, J. Strat. Market., 6, 1, 320-342, 2013, http://dx.doi.org/10.1108/JSMA-03-2013-0015.

[14] Liu Y., Wei J., Business modeling for entrepreneurial firms: four case in China, Chin. Manag. Stud., 7, 3, 344-359, 2013, http://dx.doi.org/10.1108/CMSMar-2012-0052.

[15] Sigalas C., Economou V.P., Revisting the concept of competitive advantage Problemsand fallacies arising from its conceptualization, J. Strat. Market., 6, 1, 61-80, 2013, http://dx.doi.org/10.1108/17554251311296567.

[16] Atkin T., Gilinsky Jr. A., Newton S.K., Enviromental Strategy: does it lead to competitive advantage in the US Wine industry? Int. J. of. Wine. Bus. Res., 24, 2, 115-133, 2012, http://dx.doi.org/10.1108/17511061211238911.

[17] Rugraff E., The new competitive advantage of Automobile Manufacturers, J. Strat. Market., 5, 4, 407419, 2012, http://dx.doi.org/10.1108/17554251211276371.

[18] Devaraj S., Krajewski L., Wei J.C., Impact of eBusiness technologies on operational performance: the role of production information integration in the supply chain, J. Oper. Manag., 25, 1199-1216, 2007, http://dx.doi.org/10.1016/j.jom.2007.01.002.

[19] Ismail M.D., Khairy K., Domil A., Isa A.M., Managerial Competence, Relationship Quality and Competitive Advantage among SME Exporters, Soc. Behav. Sci., 115, 138-146, 2013, http://dx.doi.org/10.1016/j.sbspro.2014.02.422. 
[20] Agus A., Hassan Z.F., Enhancing Production Performance and Customer Performance Through Total Quality Management (TQM): Strategies For Competitive Advantage, Soc. Behav. Sci., 24, 16501662, 2011

http://dx.doi.org/10.1016/j.sbspro.2011.09.019.

[21] Talib F., Rahman Z., Qureshi M.N., A study of total quality management and supply chain management practices, Int. J. Prod. Perform. Manag., 60, 3, 268288, 2011,

http://dx.doi.org/10.1108/17410401111111998.

[22] Singh N., Adoption of industry-specific quality management system standards: determinants for auto component firms in India, Int. J. Prod. Qual. Manag., 5, 1, 88-107, 2010.

[23] Islam M., Karim A., Manufacturing practices and performance Comparison among small-medium and large industries, Int. J. Qual. Reliab. Manag., 28, 1, 43-61, 2009, http://dx.doi.org/10.1108/02656711111097544.

[24] Ram J., Wu M-L., Tagg R., Competitive advantage from ERP projects: Examining the role of key implementation drivers, Int. J. Proj. Manag., 32, 663675, 2014,

http://dx.doi.org/10.1016/j.ijproman.2013.08.004.

[25] Soni G., Kodali R., The strategic fit between "competitive strategy" and "supply chain strategy" in Indian manufacturing industry: an empirical approach, Meas. Bus. Excel., 15, 70-89, 2011, http://dx.doi.org/10.1108/13683041111131637.

[26] Lin Y.C., Tsai P.H., The impact of a global logistics integration system on localization service and business competitive advantage, Eur. Bus. Rev., 21, 418-437, 2009, http://dx.doi.org/10.1108/09555340910986655.

[27] Wong C.Y., Karia N., Explaining the competitive advantage of logistics service providers: a resourcebased view approach, Int. J. Prod. Econ., 128, 51-67, 2009, http://dx.doi.org/10.1016/j.ijpe.2009.08.026

[28] Han S-L., Sung H-S., Shim H-S., Antecedents and performance outcomes of flexibility in industrial customer - supplier relationships, J. Bus. Res., 67, 2115-2122, 2014,

http://dx.doi.org/10.1016/j.jbusres.2014.04.020.

[29] He Y., Lai K.K., Hongyi S., Chen S.Y., The impact of supplier integration on customer integration and new product performance:The mediating role of manufacturing flexibility under trust theory, Int. J. Prod. Econ., 147, 260-270, 2014, http://dx.doi.org/10.1016/j.ijpe.2013.04.044.

[30] Santos-Vijande M.L., Lopez-Sanchez J.A., Trespalacios J.A., How organizational learning affects a firm's flexibility, competitive strategy, and perfor- mance, J. Bus. Res., 65, 1079-1089, 2012,

http://dx.doi.org/10.1016/j.jbusres.2011.09.002.

[31] European Commission, The concept of clusters and cluster policies and their role for competitiveness and innovation: Main statistical results and lessons learned, Luxembourg: Office for Official Publications of the European Communities, 2008, http://tinyurl.com/htxqnby [accessed on September 1, 2016].

[32] Niu K., Organizational trust and knowledge obtaining in industrial clusters, Journal of Knowledge Management, 14, 141-155, 2010, http://dx.doi.org/10.1108/13673271011015624.

[33] Lin C., Jiang J.L., Wu Y.J., Chang C.C., Assessment of commercialization strategy using RED capability, Ind. Manag. Data. Syst., 111, 3, 341-369, 2010 , http://dx.doi.org/10.1108/02635571111118251.

[34] Moyano-Fuentes J., Sacristan-Díaz M., MartínezJurado P.J., Cooperation in the supply chain and lean production adoption: evidence from the Spanish automotive industry, Int. J. Oper. Prod. Manag., 32, 9, 1075-1096, 2012, http://dx.doi.org/10.1108/01443571211265701.

[35] Wadhwa S., Bhoon K.S., Chan F.T.S., Postponement strategies through business process redesign in automotive manufacturing: knowledge innovation, Ind. Manag. Data. Syst., 106, 3, 307-326, 2006, http://dx.doi.org/10.1108/02635570610653470.

[36] Binder M., Gust P., Clegg B., The importance of collaborative frontloading inautomotive supply networks, J. Manuf. Tech. Manag., 19, 3, 315-331, 2008, http://dx.doi.org/10.1108/17410380810853759.

[37] Oh J., Rhee S-K., Influences of supplier capabilities and collaboration in new car development on competitive advantage of carmakers, Manag. Decis., 48, 5, 756-774, 2010, http://dx.doi.org/10.1108/00251741011043911.

[38] Pillania R.K., Creation and categorization of knowledge in automotive components SMEs in India, Manag. Decis., 46, 10, 1452-1464, 2008, http://dx.doi.org/10.1108/00251740810919986.

[39] Niebecker K., Eager D., Kubitza K., Improving cross-company project management performance with a collaborative project scorecard, Int. J. Proj. Manag. Bus., 1, 3, 368-386, 2008, http://dx.doi.org/10.1108/17538370810883828.

[40] Cane T., Tyler B.B., Alliance portfolio RGD intensity and new product introduction, Am. J. Bus., 28, 1, 38-63, 2013, http://dx.doi.org/10.1108/19355181311314761. 
[41] Porporato M., Timing and drivers of management control systems in joint ventures: the effect on JV survival, Q. R. A. M., 6, 4, 247-274, 2009, http://dx.doi.org/10.1108/11766090910989518.

[42] Chowdhury R.R., Joint venture instability and monitoring, Indian Growth and Development Review, 2, 2, 126-140, 2009, http://dx.doi.org/10.1108/17538250910992559.

[43] Peppard J., Rylander A., Products and services in cyberspace, Int. J. Inform. Manga: J. Inform. Prof., 25, 4, 335-345, 2005, http://tinyurl.com/gnttd5o [accessed on September 2, 2016].

[44] Wang B., Moon Y.B., Hybrid modeling and simulation for innovation deployment strategies, Ind. Manag. Data. Syst., 113, 1, 136-154, 2013, http://dx.doi.org/10.1108/02635571311289719.

[45] Wong S. K-S., The influence of green product competitiveness on the success of green product innovation: empirical evidence from the Chinese electrical and electronics industry, Eur. J. Innovat. Manag., 15, 4, 468-490, 2012, http://dx.doi.org/10.1108/14601061211272385.

[46] Leung Y.K., Choy K.L., Kwong C.K., A realtime hybrid information-sharing and decision support system for the mold industry, J. High. Tech. Manag. Res., 21, 64-77, 2010, http://dx.doi.org/10.1016/j.hitech.2010.02.008.

[47] Narvekar R.S., Jain K., A new framework to understand the technological innovation process, J. Intellect. Capital., 7, 2, 174-186, 2006, http://dx.doi.org/10.1108/14691930610661845.

[48] Williams C., Ecker B., RESD subsidiary embedment: a resource dependence perspective, Critical Perspectives on International Business, 7, 4, 297-325, 2011, http://dx.doi.org/10.1108/17422041111180764.

[49] Park C., Vertinsky I., Lee C., Korean international joint ventures: how the exchange climate affects tacit knowledge transfer from foreign parents, Int. Market. Rev., 29, 2, 151-174, 2011, http://dx.doi.org/10.1108/02651331211216961.

[50] Chen S-C., Minh P.S., Chang J-A., Huang S-W., Huang C-H., Mold temperature control using high-frequency proximity effect induced heating, Int. Comm. Heat. Mass. Tran., 39, 216-223, 2012, http://dx.doi.org/10.1016/j.icheatmasstransfer.2011. 11.006 .

[51] Wu W-W., Yu B., Wu C., How, China's equipment manufacturing firms achieve successful independent innovation: the double helix mode of technological capability and technology management, Chin. Manag. Stud., 6, 1, 160-183, 2012, http://dx.doi.org/10.1108/17506141211213915.
[52] Folgado R., Pecas P., Henriques E., Life cycle cost for technology selection: a case study in manufacturing of injection moulds, Int. J. Prod. Econ., 128, 368-378, 2010,

http://dx.doi.org/10.1016/j.ijpe.2010.07.036.

[53] Cingoz A., Akdogan A.A., Strategic flexibility, environmental dynamism, and innovation performance: An empirical study, Soc. Behav. Sci., 99, 582-589, 2013 , http://dx.doi.org/10.1016/j.sbspro.2013.10.528.

[54] Lofberg N., Witell L., Gustafsson A., Service strategies in a supply chain, Int. J. Serv. Manag., 21, 4, 427-440, 2010,

http://dx.doi.org/10.1108/09564231011066079.

[55] Schumacker R.E., Lomax R.G., A beginner's guide to structural equation modeling, New York, USA: Routledge, 2010.

[56] Cunningham E., A practical guide to Structural Equation Modelling using AMOS, Melbourne, Australia: Statsline, 2008.

[57] Weston R., Gore P.A., A brief guide to structural equation modeling, The Counseling Psychologist, 34, 5, 719-751, 2006, http://dx.doi.org/10.1177/0011000006286345.

[58] Worthington R.L., Whittaker T.A., Scale development research: a content analysis and recommendations for best practices, J. Counsel. Psychol., 34, 6, 806-837, 2006, http://dx.doi.org/10.1177/0011000006288127.

[59] Meldrum K., Structural equation modeling: tips for getting started with your research, C.A.R.M. Sci. Health. Environ Educ., pp. 1-5, 2010, http://tinyurl.com/hq5peqq [accessed on September $1,2016]$.

[60] Hair J.F., Black W.C., Babin B., Anderson R.E., Tatham R.L., Multivariate Data Analysis, 6th Ed. New Jersey, USA: Pearson Education, 2006.

[61] Likert R., A technique for the measurement of attitudes, Attitude Assessment, G.F. Summers [Ed.], Chicago, Ill., USA: Rand-McNally and Company, pp. 149-158, 1970.

[62] Ireland R.D., Webb J.W., Strategic entrepreneurship: creating competitive advantage through streams of innovation, Bus. Horiz., 50, 49-59, 2007, http://dx.doi.org/10.1016/j.bushor.2006.06.002.

[63] Lauro C., Vinzi V.E., Amato S., PLS typological regression: algorithmic, classification and validation issues, New Developments in Classification and Data Analysis, M. Vichi, P. Monari, S. Mignani, A. Montanari [Eds.], Berlin, Germany: Springer, pp. 133-140, 2004. 
[64] Henseler J., Fassott G., Testing moderating effects in PLS path models: an illustration of available procedures, Handbooks of Computational Statistics, Springer, pp. 713-735, 2010.

[65] Huang Y-T., Learning from cooperative interorganizational relationships: the case of international joint venture, J. Bus. Ind. Market., 25, 6, 454-467, 2011 ,

http://dx.doi.org/10.1108/08858621011066044.
[66] Ahmad S., Schroeder R.G., Knowledge management through technology strategy: implications for competitiveness, J. Manuf. Tech. Manag., 22, 1, 624, 2011, http://dx.doi.org/10.1108/17410381111099789.

[67] Porter M., Clusters and the New Economics of Competition, Harvard Business Review, NovemberDecember, 1998, http://tinyurl.com/ntaouv6 [accessed on September 2, 2016]. 